\title{
PRELIMINARY INVENTORY OF BATS (MAMMALIA, CHIROPTERA) IN THREE PROTECTED AREAS OF THE DEMOCRATIC REPUBLIC OF THE CONGO
}

\author{
André B. Malekani' ${ }^{1}$, Prescott A. Musaba ${ }^{1}$, Guy-Crispin T. Gembu ${ }^{1}$, Elie P. Bugentho ${ }^{1}$, \\ Alfred S. Toengaho ${ }^{1}$, Gabriel B. Badjedjea ${ }^{1}$, Jean C. Ngabu ${ }^{1}$, Patrick K. Mutombo ${ }^{1}$, \\ Anne Laudisoit ${ }^{2}$, Corneille N. Ewango ${ }^{3}$, Victor Van Cakenberghe ${ }^{2}$, Erik Verheyen ${ }^{2}$, \\ Justin A. Asimonyo ${ }^{1}$, Franck M. Masudi ${ }^{1}$, Gédéon N. Bongo ${ }^{4}$, Koto-te-Nyiwa Ngbolua ${ }^{4,5, *}$ \\ ${ }^{1}$ University of Kisangani, Democratic Republic of the Congo \\ ${ }^{2}$ University of Antwerp, Belgium \\ ${ }^{3}$ Wildlife Conservation Society, Democratic Republic of the Congo \\ ${ }^{4}$ University of Kinshasa, Democratic Republic of the Congo \\ ${ }^{5}$ University of Gbadolite, Democratic Republic of the Congo \\ *e-mail:jpngbolua@unikin.ac.cd
}

Received: 18.07.2017

\begin{abstract}
As part of biodiversity monitoring in the Kisangani Forest Region, a survey of bats was conducted in three protected areas, specifically Lomami, Yangambi and Epulu. In this pilot study, a total of 201 specimens were collected using Japanese nets of different lengths (6,9 and $12 \mathrm{~m}$ long) and a height of $2 \mathrm{~m}$ with a mesh size of $2 \times 2 \mathrm{~cm}$ to capture bats. Captured specimens were identified using determination keys appropriate for the study area. The results of inventories in the three sites revealed that 201 specimens of captured bats belong to 2 sub-orders, 4 families, 9 genera and 12 species. The most abundant species were Epomops franqueti, Megaloglossus woermannii and Myotis bocagii. The following species, Epomops franqueti, Megaloglossus woermanii, Casinycteris argynnis, and Hipposideros caffer were found at all three sites. Based on the Shannon Index, it was observed that the Lomami site has a higher specific diversity than the two other areas (Yangambi and Epulu) 1.74 against 1.51 and 1.42 respectively.
\end{abstract}

Key words: biodiversity, Chiroptera, Epulu, Lomami, Protected Area, Yangambi

\section{Introduction}

Forest ecosystems are experiencing an exponential regression and their biodiversity is threatened by various anthropogenic activities, like: agriculture, overexploitation of wood, uncontrolled hunting, urbanisation, installation of industrial and commercial infrastructures, mining and daily collection of forest by-products (Vink, 1983; Katuala, 2009). The Democratic Republic of the Congo (DRC) has $9.2 \%$ of the world's humid tropical forests. The forest cover in the DRC ranks the second largest tropical forest cover after Amazon forest in Brazil (FAO, 2009; De Wasseige et al., 2009). Unfortunately, the Congolese forests have faced an increased deforestation, due to a high population growth which requires an expansion of agricultural land and human settlements since decades. In 2006, the Congolese population reached 60.2 million people and may count 108 million by 2025 according to current projection (INS, 2009).

In the $\mathrm{DRC}$, bats have no particular protection status. To the concern of the human population increase, is added the low income of this population but also the need for proteins of animal origin is constantly turned towards wildlife. Bat collection, precisely Megachiroptera, for food is significant in forest regions where livestock farming is not common (Gembu, 2007). Inadequate hunting practices and non-compliance to hunting season restrictions constitute a real threat to the Congolese wildlife (Dudu et al., 2002).

Bats have some ecological interests in regulating insect population and contribute as well to the pollination and the dispersion of plant seeds; socio-economic as a source of animal proteins for the local population. In public health, these animals are reservoirs and vectors of several diseases in humans and animals, like Ebola, SARS, rabies, and their guano (excrement) is used as fertilisers and for manufacturing soaps, gasohol and antibiotics. Knowing the importance of bats, especially in public health as host of emerging viruses, there is a need of more inventory studies in order to state about its biodiversity in the DRC and these bats may be screened for the identification of various viral diseases (Calisher et al., 2006).

Nevertheless, myths and misunderstandings about the roles of bats in ecosystems and their 
danger to other species as hosts of the rabies virus have led to efforts to extirpate bat populations, with serious consequent effects on insect control and crop production, without coincidental reduction in the low incidence of rabies virus transmission (Calisher et al., 2006).

Several authors have reported that small animal species taxonomy and distribution is poorly known in Tropical Africa (Quérouil, 2001; Plana, 2004; Katuala, 2009). In the present day, studies of bats' ecology are getting increasingly important for a number of reasons. For instance, in medical biology, some bat species are vectors or hosts of potential viral human diseases but they also serve as material for epidemiological monitoring. The role of these animals in natural habitat conservation is an ecological asset for a sustainable management of forest regions (Fleming, 1993). In Kisangani studies on bats are scanty; several areas are still unexplored due to the inaccessibility (lack of road infrastructure) and insecurity. All this means that, in Kisangani region, research on bats is still in the preliminary phase.

Since 2004, some surveys on bats were carried out at the Faculty of Science, University of Kisangani and we can report the study carried in the Yoko Forest Reserve by Gembu $(2007,2012)$ as well as Ngohe (2013) in the Zoological Garden and Kisangani Arboretum. In the Kisangani ecoregion, literature on bats is scanty and limited to some locations, leaving large areas to remain including Protected Areas in the region. The current study contributes to the update of bat biodiversity knowledge of Kisangani ecoregion (located in DRC) and its surroundings. This ecoregion has several forest blocks which in fact form ecological gradients of various habitat types ranging from fallow, primary and secondary forests to human modified habitats.

It is expected that the diversity in types of habitats in the area could induce faunistic diversity including that of bats. It is for this reason that the surveys we report now were conducted in these areas to assess the bat fauna. The main objective of the study was to perform a preliminary inventory of bats in Kisangani ecoregion specifically in three protected areas (Lomami, Yangambi and Epulu) in the DRC.

\section{Material and Methods}

Study area

Inventories of bat fauna of three protected areas (Fig.) in the framework of scientific missions funded by VLIR-UOS called «Boyekoli Congo» were conducted between February 2013 and September 2015. In total, three missions were conducted in Lomami (Mission I), Yangambi (Mission II) and Epulu (Mission III) respectively.

The first mission (Mission I) was undertaken in Lomami-Lualaba-Tshuapa National Park (TL2) where surveys were based at Obenge (25 53'44.6" E, $\left.01^{\circ} 00^{\prime} 03.865^{\prime \prime} \mathrm{S}\right)$ between 25 January and 12 February, 2013. Mission II in Yangambi Biosphere Reserve $\left(00^{\circ} 45^{\prime} 344^{\prime \prime} \mathrm{N}\right.$ and $24^{\circ} 28^{\prime} 31.1^{\prime \prime}$ E) was conducted between 24 March and 02 April, 2015 based at an area of INERA. Mission III was carried out in Okapi Wildlife Reserve (Epulu) $\left(01^{\circ} 23^{\prime} 53.088^{\prime \prime} \mathrm{N}\right.$ and E $\left.28^{\circ} 34^{\prime} 7.248^{\prime \prime} \mathrm{E}\right)$ between 22 August and 05 September, 2015 where the surveys conducted were based in Epulu city.

\section{Methods}

Six Japanese nets of different lengths (6, 9 and $12 \mathrm{~m}$ long) and a height of $2 \mathrm{~m}$ with a mesh size of $2 \times 2 \mathrm{~cm}$ were used to capture bats in our survey. A total of 201 bat specimens were collected (69 in Lomami, 56 in Yangambi and 76 in Epulu). At each netting site, grasses were cleared using a machete and this allowed the net installation. The net was fixed on two poles firmly fixed on the ground and stretched in different habitats at strategic points (corridors) or next to fruit trees suspected to host bats between 18:30 and 6:30. The netting effort was the same for the three survey areas and they had the same structure.

All captured bats were placed in a holding bag with a tag showing details of where it was captured until it was eventually processed. A number of morphometric dimensions were measured for each captured bat according to Kingdom's (2010) identification keys and Patterson \& Webala (2012) following which each individual was euthanised and various organs (liver, heart, lungs, muscles) collected. Organs recovered were held in Ependorff tubes containing alcohol $70 \%$ and will be used for molecular analysis. The remains of carcasses each with a numbered foot label were stored in formalin $4 \%$.

From the captured specimens, we computed the following parameters: Shannon index, Equitability and the Constance.

\section{Results}

Biodiversity of Bats

The taxonomic inventory, numbers per site and the Constance (C) of species are presented in Table. 


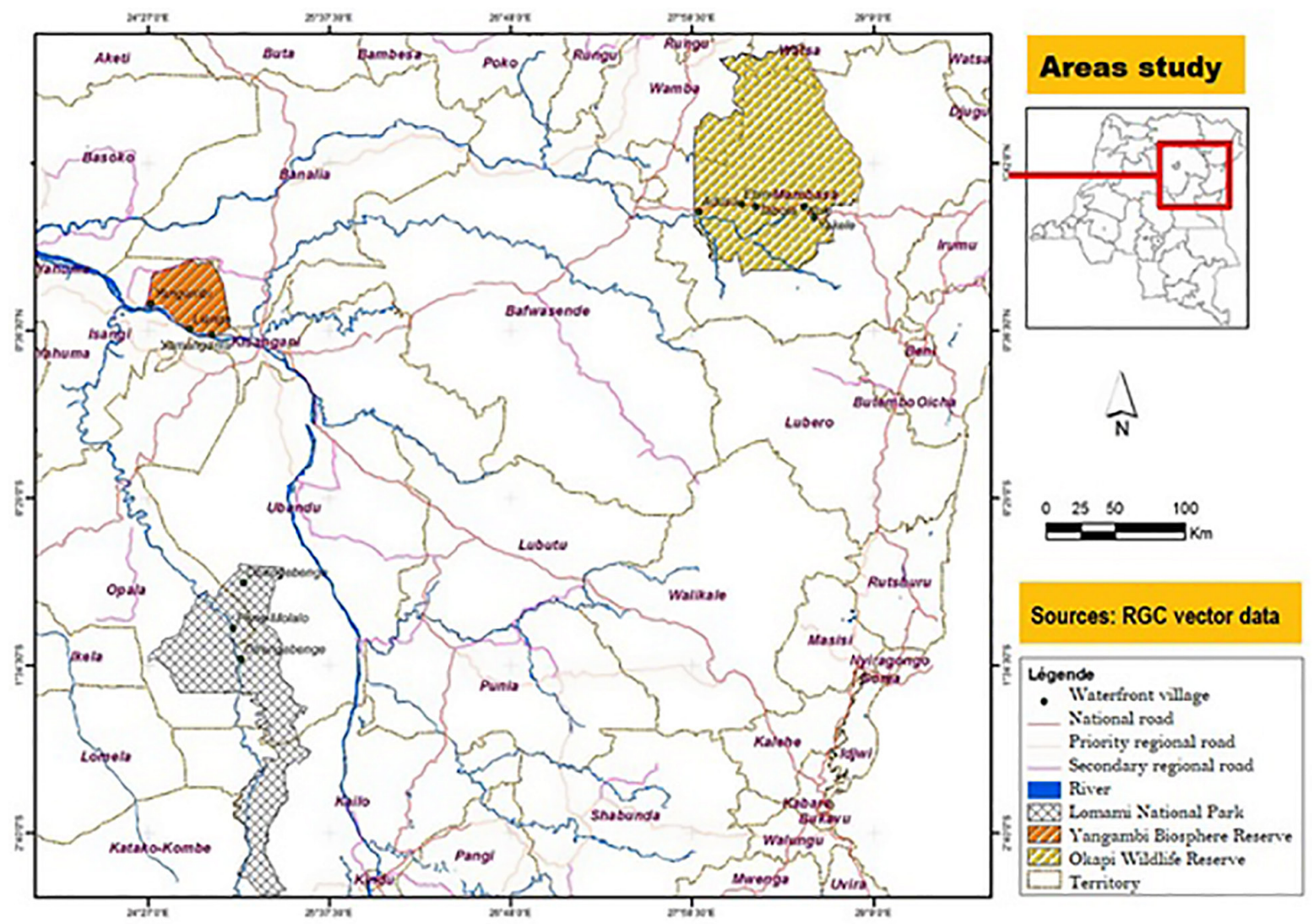

Fig. Locations of the three Protected Areas in which the surveys were conducted.

Table. Taxonomic inventory, numbers per habitat and degree of constancy of species.

\begin{tabular}{|c|c|c|c|c|c|c|c|c|}
\hline Sub-order & Family & Genera & Species & Lomami & Yangambi & Epulu & Total & $\mathrm{C}(\%)$ \\
\hline \multirow{5}{*}{ Megachiroptera } & \multirow{5}{*}{ Pteropodidae } & Casinycteris & C. argynnis Thomas, 1910 & 10 & 14 & 1 & 25 & 100 \\
\hline & & Epomops & E. franqueti (Tomes, 1860) & 15 & 15 & 20 & 50 & 100 \\
\hline & & Megaloglossus & $\begin{array}{l}\text { M. woermannii } \\
\text { Pagenstecher, } 1885\end{array}$ & 4 & 4 & 34 & 42 & 100 \\
\hline & & Myonycteris & M. torquata (Dobson, 1878) & 0 & 19 & 7 & 26 & 66.6 \\
\hline & & Scotonycteris & S. zenkeri Matschie, 1894 & 0 & 1 & 2 & 3 & 66.6 \\
\hline \multirow{7}{*}{ Microchiroptera } & \multirow{4}{*}{ Hipossideridae } & \multirow{4}{*}{ Hipposideros } & H. caffer (Sundevall, 1846) & 6 & 2 & 1 & 9 & 100 \\
\hline & & & $\begin{array}{l}\text { H. cyclops (Temminck, } \\
\text { 1853) }\end{array}$ & 4 & 0 & 0 & 4 & 33.3 \\
\hline & & & H. rubber (Noack, 1893) & 2 & 0 & 11 & 13 & 66.6 \\
\hline & & & H. gigas Wagner, 1845 & 1 & 0 & 0 & 1 & 33.3 \\
\hline & \multirow[b]{2}{*}{ Vespertilionnidae } & Myotis & M. bocagii (Peters, 1870) & 26 & 0 & 0 & 26 & 33.3 \\
\hline & & Pipistrellus & $\begin{array}{l}\text { P. hesperidus (Temminck, } \\
\text { 1840) }\end{array}$ & 0 & 1 & 0 & 1 & 33.3 \\
\hline & Nycteridae & Nycteris & N. arge Thomas, 1903 & 1 & 0 & 0 & 1 & 33.3 \\
\hline \multicolumn{4}{|l|}{ Total } & 69 & 56 & 76 & 201 & 100 \\
\hline \multicolumn{4}{|l|}{ Percentage } & 34.3 & 27.9 & 37.8 & 100 & - \\
\hline \multicolumn{4}{|l|}{ Specific richness } & 9 & 7 & 7 & 12 & - \\
\hline \multicolumn{4}{|l|}{ Shannon index } & 1.74 & 1.51 & 1.42 & - & - \\
\hline \multicolumn{4}{|l|}{ Equitability } & 0.79 & 0.77 & 0.72 & - & - \\
\hline
\end{tabular}


Table presents the distribution of the 201 specimens of bats we captured at the three sites. The captured bats belong to four families: Pteropodidae (5 species), Hipossidaridae (4 species), Vespertionnidae (2 species) and Nicteridae (one species). The site of Obenge produced more species ( 9 species) than the two other sites ( 7 species each).

Lomami provided 69 specimens divided in 9 species of which Myotis bocagii was the most abundant species followed by Epomops franqueti. Yangambi provided 56 specimens grouped into 7 species, among which Myonycteris torquata was the most abundant followed by Epomops franqueti while in Epulu provided 76 specimens of 7 species of which Megaloglossus woermannii was the most represented, followed by Epomops franqueti.

The following species Casinycteris argynnis, Epomops franqueti, Megaloglossus woermannii, Hipposideros caffer, Myonycteris torquata, Scotonycteris zenkeri, and Hipposideros ruber are constant while Hipposideros cyclops, Hipposideros gigas, Myotis bocagii, Pipistrelus hesperidus, and Nycteris arge are incidental species. Epomops franqueti was the most abundant species found at the three sites.

\section{Discussion}

The results reported here are from surveys carried out in three protected areas, namely Lomami, Yangambi and Epulu. The results are by no means a complete description of the full bat fauna of any of the survey areas, but only an initial documentation for the areas. From the three different survey areas, altogether we recorded five of the 11 species of Megachiroptera known for the Democratic Republic of the Congo and only 7 of the 55 known species of Microchiroptera.

Based on the Shannon diversity index, the results clearly show that Lomami has a higher specific richness (1.74) than the two other, Yangambi (1.51) and Epulu (1.44). Based on numbers of captured bats, the results suggest that Epulu might have a higher overall population of bats than the two other sites. The observed difference may be due to the floristic composition or to different seasonal periods of collection. Species like Epomops franqueti, Megaloglossus woermannii, Casinycteris argynnis, and Hipposideros caffer were present in all three protected areas. These findings are similar with Ngohe (2013) who reported the presence of Casinycteris argynnis and Megaloglossus woermannii in all study areas he surveyed, namely Kisangani Zoological Garden, Yoko Arboretum and Yoko Forest Reserve.
Quantitatively, Epomops franqueti was the most commonly captured species in the overall (50 specimens) followed by Megaloglossus woermannii (42 specimens). Gembu (2007) and Ifuta (1993) in Yoko Forest Reserve and Masako Forest Reserve also found that Epomops franqueti was the most numerous bat species in their collection. Just like Gembu (2012), our results suggest that small mammals are represented generally with numerous species in Equatorial forest; populations are composed of a numerically dominant species represented by a very large number of individuals and others represented by individuals who are in a much lower density. Several studies carried out in other African countries reported a large number of insect-eating bats in Ethiopia and Guinea (Kruskop \& Lavrenchenko, 2008; Decher et al., 2015) but this is not the case of the current survey. The disproportion between the captured fruit bats and insectivorous bats can be explained by the fact that the former, due to the peculiarities of their biology, are on the whole easy to capture in the mist nets.

\section{Conclusions}

The main purpose of this study was to conduct a preliminary inventory of bats in and around Kisangani Ecoregion specifically in three protected areas (Lomami, Yangambi and Epulu).We recorded species of bats from 2 sub-orders, 4 families, 9 genera and 12 species. The family of Pteropodidae were represented by more species than any other of the families recorded. Four species of bats - Epomops franqueti, $\mathrm{Me}$ galoglossus woermannii, Casinycteris argynnis and Hipposideros caffer, were found in all the three areas. Further studies are needed in order to make a systematic inventory of bats found in Kisangani ecoregion and for the molecular analysis of different organs collected after capture.

\section{References}

Calisher C.H., Childs J.E., Field H.E., Holmes K.V., Schountz T. 2006. Bats: Improtant Reservoir Hosts of Emerging Viruses. Clinical Microbiology Reviews 19(3): 531545. DOI: 10.1128/CMR.00017-06

Decher J., Hoffmann A., Schaer J., Norris R.W., Kadjo B., Astrin J., Monadjem A., Hutterer R. 2015. Bat diversity in the Simandou Mountain Range of Guinea, with the description of a new white-winged Vespertilionid. Acta Chiropterologica 17(2): 255-282.

De Wasseige C., Devers D., de Marcken P., Eba'a Atyi R., Nasi R., Mayaux P. 2009. Les forêts du bassin du Congo-Etat des forêts 2008. Luxembourg: Office des publications de l'Union Européenne. 426 p. DOI: $10.2788 / 32456$ 
Dudu A., Mate M., Gambalemoke M., Danadu M., Gembu T., Kaswera K. 2002. La précarité de l'exploitation des ressources naturelles renouvelables : cas de la flore de la province orientale (RDC) en cette période de guerres et de la recherche de la paix. Kinshasa: Fondation Konrad Adenauer. P. 65-85.

FAO. 2009. Situation des forêts du monde. Rome: FAO. 152 p.

Fleming T.H. 1993. Plant-visiting bats. American Scientist 81: 460-467.

Gembu T. 2012. Population and food dynamics of fruiteating Chiroptera (Mammalia) of the yoko forest reserve (Orientale Province). Thèse inédite. Kinshasa: University of Kinshasa. 172 p.

Gembu T. 2007. Pteropodidae (Megachiroptera, Mammalia) from the Kisangani region (DR Congo): Biometrics, ecological distribution and population structure. Master's Thesis. Kinshasa: University of Kinshasa. 55 p.

Ifuta N. 1993. Ecological and hormonal parameters during the growth and reproduction of Epomops franqueti (Mammalia: Chiroptera) of the equatorial rainforest of Masako (Kisangani, Zaire). PhD Thesis. KUL. 142 p.

INS. 2009. Bulletin of General Statistics. $2^{\text {nd }}$ quarter. Democratic Republic of the Congo.

Katuala G.B. 2009. Biodiversity and biogeography of Myomorphic and Sciuromorphic rodents (Rodentia: Mammalia) of some forest blocks in the Kisangani region (DR Congo). PhD Thesis. Kisangani. 149 p.
Kingdom J. 2010. Guide des Mammifères d'Afrique. Paris: Eds Delachaux et Niestlé. 272 p.

Kruskop V.S., Lavrenchenko A.L. 2008. Primary results of a bat survey in south-western Ethiopia, with a new Ethiopian record of Kerivoula lanosa (Chiroptera: Vespertilionidae). Russian Journal of Theriology 7(2): 71-76.

Ngohe T. 2013. Evolution of Catch and Distribution of Chiroptera (Mammalia) in the Kisangani Region (Kisangani, R.D.Congo): Case of the Zoological Garden, the Kisangani Arboretum and the Yoko Forest Reserve. Unpuplished manuscript. Kinshasa: University of Kinshasa. 53 p.

Plana V. 2004. Mechanisms and tempo of evolution in the African Guineo-Congolian rainforest. Philosophical Transactions B 359(1450): 1585-1594. DOI: 10.1098/ rstb.2004.1535

Patterson D.B., Webala W.P. 2012. Keys to the Bats (Mammalia: Chiroptera) of East Africa. Fieldiana Life and Earth Sciences 6: 1-60. DOI: 10.3158/2158-5520-12.6.1

Quérouil S. 2001. Interests and limitations of the molecular approach to address biogeography and speciation: the example of some mammals from tropical Africa. PhD Thesis. Rennes: University of Rennes $1.310 \mathrm{p}$.

Vink A.P.A. 1983. Landscape ecology and land use. New York: Longman. 264 p.

\title{
ПРЕДВАРИТЕЛЬНАЯ ИНВЕНТАРИЗАЦИЯ РУКОКРЫЛЫХ (МАММАLІА, CHIROPTERA) ТРЕХ ОСОБО ОХРАНЯЕМЫХ ПРИРОДНЫХ ТЕРРИТОРИЙ ДЕМОКРАТИЧЕСКОЙ РЕСПУБЛИКИ КОНГО
}

\author{
А. А. Малекани ${ }^{1}$ П. А. Мусаба ${ }^{1}$, Г.-К. Т. Гембу ${ }^{1}$, Е. П. Бугенто ${ }^{1}$, А. С. Тоагао ${ }^{1}$, \\ Г. Б. Баджеджа ${ }^{1}$, Ж. С. Нгабу ${ }^{1}$, П. К. Мутомбо ${ }^{1}$, А. Лодизоуа ${ }^{2}$, К. Н. Еванго ${ }^{3}$,
} В. ван Какенберге ${ }^{2}$, Э. Верхайен ${ }^{2}$, Дж. А. Асимонйо ${ }^{1}$, Ф. М. Масуди ${ }^{1}$, Г. Н. Бонго ${ }^{4}$, К. Н. Нгболуа ${ }^{4,5}$,*

\author{
${ }^{1}$ Университет Кисангани, Демократическая Республика Конго \\ ${ }^{2}$ Университет Антверпена, Бельгия \\ ${ }^{3}$ Общество Охраны Дикой Природы, Демократическая Республика Конго \\ ${ }^{4}$ Университет Киншасы, Демократическая Республика Конго \\ ${ }^{5}$ Университет Гдаболите, Демократическая Республика Конго \\ *e-mail:jpngbolua@unikin.ac.cd
}

\begin{abstract}
В рамках инвентаризации биоразнообразия лесного региона Кисангани было проведено исследование рукокрылых в трех особо охраняемых природных территориях (ООПТ) - Ломами, Янгамби и Эпулу. В результате этого исследования, был собран 201 образец с использованием японской сети разной длины $(6,9$ и 12 м) и 2 м высотой с размером ячеи $2 \times 2$ см. Пойманные особи были определены с помощью ключей для определения рукокрылых изученной территории. Результаты исследования трех ООПТ показали, что 201 пойманная особь относится к 2 подотрядам, 4 семействам, 9 родам и 12 видам. Epomops franqueti, Megaloglossus woermannii и Myotis bocagii были представлены наибольшим числом пойманных особей. Виды Epomops franqueti, Megaloglossus woermanii, Casinycteris argynnis и Hipposideros caffer были обнаружены на всех трех ООПТ. На основании индекса Шеннона было обнаружено, что местообитание Ломами характеризуется более высоким значением видового разнообразия (1.74), чем две остальные ООПТ - Янгамби (1.51) и Эпулу (1.42).
\end{abstract}

Ключевые слова: Chiroptera, биоразнообразие, Ломами, особо охраняемая природная территория, Эпулу, Янгамби 